\title{
Approaches for Generating and Evaluating Product Positioning Strategy
}

\author{
Oghojafor Ben Akpoyomare \\ Department of Business Administration, University of Lagos, Nigeria \\ E-mail: akpoyomareo@yahoo.co.uk \\ Ladipo Patrick Kunle Adeosun \\ Department of Business Administration, University of Lagos, Nigeria \\ E-mail: patrickladipo@yahoo.com \\ Rahim Ajao Ganiyu (Corresponding author) \\ Department of Business Administration, University of Lagos, Nigeria \\ Tel: 234-803-319-9942Ｅ-mail: Abdulrahimajao@yahoo.com
}

Received: September 18, 2012

Accepted: November 13, 2012

Online Published: January 5, 2013

doi:10.5430/ijba.v4n1p46

URL: http://dx.doi.org/10.5430/ijba.v4n1p46

\begin{abstract}
Product positioning has been an important part of marketing since companies began to recognize the relevance of having control over their image. It is also a way of influencing consumer perception and purchase decisions as well as to satisfy corporate sales objectives.

Developing an appropriate 'product positioning strategy' is usually influenced by such factors as the competitive marketplace, specific corporate goals, and organizational strengths. Once established, it has typically become a posture that influence and direct marketing communications. This paper investigates the approaches for generating and evaluating product positioning strategy, using descriptive research approach. The paper concludes that positioning is applicable to products in the broadest sense. However, Institutions, Organizations or even Countries can benefit from a well developed positioning strategy that focuses on a niche that is unoccupied in the mind of the consumer.
\end{abstract}

Keywords: Positioning, Brand, Product, Consumer perception, Choice decision, Buying behavior

\section{Introduction}

Positioning relate essentially to the mind of the consumers. The positioning of a brand in an industry/product category ultimately depends on the consumer, and how they perceive the quality, attributes, value, price, and image of the brand. In other word, it is the concept of a brand that is held by the consumer (Keller, 2008; Vukasovic, 2009). The long term overall objective of positioning is to build a brand equity, which will in turn achieve a positive long-term purchase behavior (Keller, 2008). The term positioning is an all-encompassing concept and it has long been recognized as a core branding activity (Aaker and Shansby, 1982; Ries and Trout, 2001). Therefore, more attention should be given to its meaning, importance and its application, especially as practitioners and researchers may interpret it differently.

The positioning decision is a crucial strategic decision for a brand because the brand position is central to consumer's perceptions and choice decisions (Keller, 1993). Therefore, "a good understanding of what positioning entails is a key requisite for anyone involved in nation-brand development" (Dinnie, 2008, p.51). For instance, 'University of Lagos' claims to be the University of First Choice and the Nation's pride, 'University of Ilorin' claims she is better by far. The above claims not only help to establish a primary basis of differentiation, but can also influence judgments and perception of the institutions. Positioning is regarded by some scholars as the last stage, after product and image stages, in domain of marketing communication. Positioning strategy, in general, is the expression of applications of a product and brand to consumers and to occupy a specific location against competitors in consumers mind with the intention of claiming superiority over competitors. 
The word 'positioning' is one of the "invisible assets" of the firm (Hiroyuki and Thomas, 1987). According to Wind and Saaty (1980) positioning encompasses and emphasizes most of the common meanings of the word position - as a place (what place does the product occupy in a given market?), a comparative basis (how is the product performing against its competitors in various evaluative criteria?), and as a mental attitude (how does the consumer perceive the product?). Positioning is the process of designing the company's offering and image to occupy a distinctive place in the minds of the target market" (Kotler and Keller, 2006).

The term 'positioning' was first coined by Ries and Trout. As advertising expert, they saw positioning as a matter for communications (Ries and Trout, 1981; 2001). Over the years 'positioning' has come to mean a lot of things and it has occasionally been used as a substitute word for branding. It is the definition of what the product stand for the customers and it contains communication agenda regarding the images of the brands that company's offer, which invariably influences product interpretation.

Generating an appropriate 'position' is usually influenced by such factors as the competitive marketplace, specific corporate goals and organizational strengths. It is often a process driven by the desire to find a unique position among competitors as well as to satisfy corporate sales objectives.

The starting point in generating a positioning strategy is to initially determine attributes and images of competitors' brands and then generate a competitive positioning strategy for their own product/image.

Micheal and Fred (1993) view positioning from three perspectives (which they call "merit disciplines"): product leadership, operational superiority and customer intimacy. Some customers' regards a company's offering as the best product of its class, others prefers the most productive company, and many others like the company which offers the best solutions for their needs. Pham and Muthukrishnan (2002), classify positioning into two- abstract and attribute-specific. An abstract positioning is general, and summarizes the product's features (e.g. Ultimate Driving Machine; Best Television Picture). In contrast, an attribute - specific positioning is specific, and details the product's features through specific performance claims (e.g. Brightest Liquid Crystal Display- LCD Television Screen). The authors specifically highlighted the effectiveness of an abstract position versus an attribute specific position and concluded that abstract positions were more memorable and more defensible than specific positions in certain instances.

Positioning in a nutshell is a way of emphasizing the distinctive characteristics/features of a product (brand) that make it different from its competitors and appealing to the public. It has also been recognized as a strategy companies adopt in today's me-too market place (Ries and Trout, 2001). In other words product positioning is a functional affair, with an emphasis on product and service features, benefits and usage, value and ability to solve problems for consumers (Kapferer, 1997).

While most firms acknowledge the need to differentiate their product or service from competitive offerings, executing an effective positioning strategy is a difficult task. The trends in today's business environment make positioning more complicating, and undermine the application of previously used positioning approaches. With the internet, information flows more freely than in the past and this exposes similarities between competitive products, and also provides ample opportunity for imitation. As a result, many organizations face a commodity situation with direct price and feature competition (Porter, 1980; Levitt, 1991). Also long-term brand-customer relationships are difficult to establish and maintain in such situations, this prompted a significant shift in business practice.

Although, researchers have made considerable advances in our understanding of positioning strategy, measurement and representation (e.g., Lovelock and Weinberg, 1989; Kotler and Andreasen, 1996; Carroll and Green, 1997; Green et al., 2000; Hooley et al., 2001 etc), both practitioners and academics have called for more research that develops the conceptual and strategic aspects of positioning practice (Myers, 1996; Alden et al., 1999). There are little theoretical/conceptual frameworks to guide positioning research and also, the extant positioning literature is largely normative and the issues discussed tend to be anecdotal (Chew, 2005).

The current study seeks to address some of these gaps and offers further theoretical insight into the conceptualization and relevance of positioning strategy in different organization and market contexts. Furthermore, the study evaluates major approaches for generating and evaluating positioning strategy as well as the factors that determine the choice of positioning strategy.

\section{Literature Review}

\subsection{Product Positioning Strategy}

A company might claim that it is better than competitors in many ways: we are the best, we are more responsive, we are reliable ..... and the list continues. Ries and Trout (2001), emphasized the need to focus on one key positioning 
concept so as to create a distinct image that will stay in the recipient's mind and provide an 'added value' which is improved through a remarkable differentiation from competitors.

A positioning strategy consists of three major components: to reveal possible competitive advantages that will create a positioning, to choose the right competitive advantages and to choose a comprehensive positioning strategy that will align with the organization's structure and consistent with the positioning objectives. Lastly, the company should adopt effective communication and distribution system to market the selected position (Kotler and Armstrong, 2006).

Some companies, instead of a single position, prefer to adopt a multi positioning strategy. Examples abound across many product and service categories, Centrum multivitamin claims to provide essential vitamins from A to Z. This positioning strategy has increased in usage due to the crowded nature of the market and increased companies capabilities (Advertising Age, 2008)

According to (Kotler and Armstrong, 2006) positioning entails communication plans regarding the development of images of the brands that companies offer. Therefore, 'being different' from competitors is a pre-requisite for creating a successful and a strong brand. This however, requires a coherent and integrated marketing plan that will create 'added value' to sustain price premium over their commodity form and communicate to consumers the perceived relevant added values.

Product or market positioning is dependent on the attitudes of the target market, and the internal conventions of the organizations. Marketing management, either tries to change product specifications according to that attitude, or tries to change the attitudes of the market. However, changing goods is easier and cheaper than changing consumers. Therefore, when the attitude of the market is so negative the product may need to be re-position. The internal conventions of firm also influence its brand values. Values expressed by brand usually centre on issues such as professionalism, hygiene, safety, personal attention etc. For example Samsung switch from developing me-too consumer electronics to innovative ones by changing from its traditionally non-transparent and hierarchic form, resulting into a brand values that is distinct, simple and innovative (Far Eastern Economic Review, 2000)

\subsubsection{Factors That Determine the Choice of Positioning Strategy}

The identification and selection of positioning strategy is a very complex task and it entails thorough marketing analysis and planning to identify the properties and the images of each of the major competitors. The outcome of competitors positioning analysis will in turn determine position for its products. At this point, company must take cognizance of the benefits that customers seek and which are not offered by competitors but are desired by the target market. In other words, right from product conceptualization stage, management must determine the attributes/features of its products or services to be presented to the market, and evaluate 'what kind of differences and superiorities they would have', and 'why they should be preferred' against competitor (Oliver, 1997).

A positioning strategy comprises of several related decisions/activities and it is the key outcome of the strategy development phase in the strategic marketing planning process (Lovelock and Weinberg, 1989; Kotler and Andreasen, 1996; Hooley et al., 1998; Hooley et al., 2001; Andreasen and Kotler, 2003). Within a strategic group, effective positioning decreases direct competition by avoiding the commodity trap of competing totally on price alone (Porter, 1980; Levitt, 1991).

In a nutshell, a product must be identified in the best way by the customers. Otherwise it will lose credibility and will not be remembered sufficiently. According to Whan et al., (1986) there are the six stages companies must examine in order to determine the right positioning strategy. These are:

i. Identify the competitors.

ii. Determine how the competitors are perceived and evaluated.

iii. Determine the competitors' positions.

iv. Analyze the customers.

v. Select the position.

vi. Monitor the position

\subsection{Different Positioning Options}

Berkman and Gilson (1987) argued that positioning is a multidimensional concept which emphasizes product features, attributes and or benefits. It is an important marketing decision that affects all marketing process. Based on the analysis of various positioning strategies, six positioning options have been identified. They are: 


\subsubsection{Features/Attributes}

Emphasizing the unique features of products and services is a common approach of positioning a product. In this case the firm uses one or more product attributes, features or benefits as the basis for positioning its product. Toyota car emphasize economy and reliability, Always sanitary pad focus on strength and absorbency as it unique selling propositions.

\subsubsection{Product Class/Benefits}

When close substitutes exist, the firm may focus on the benefits of its product class relative to other product class. Benefits are advantages that a product offers to consumers that enhance their comfort, happiness, wellbeing and the like. A benefit-based positioning has a stronger appeal than a feature based positioning. A typical benefit is the convenience which Automated Teller Machine (ATM) offers to customers to withdraw money and do other transactions 24/7 from their account.

\subsubsection{Use/Application}

In this option, the specific application or uses of the product/services are highlighted. Products can be positioned as the right product to use for a particular occasion or purpose. For example, meat pies may be targeted for consumption at school inter house sports or cultural festivals.

\subsubsection{User/Usage}

This positioning strategy is based on certain products being suited for certain users. Tantalizer has a strong position as a place to celebrate children's birthday. Gala are snack for those moments between meals and when one feels a need for something filing.

\subsubsection{Competitors}

Some firms deliberately compare themselves to competitors as a means of gaining the desired position for their product in the mind of the consumer. KIA Motors has used this approach to position some of its cars as being comparable in design, gas mileage and price to some leading import cars.

\subsubsection{Price and Quality}

Two of the key dimensions used by consumers in evaluating alternative brands are price and quality. Some firms use a high price (premium pricing) strategy to indicate that their product is superior in quality. Other firms use a lower price. For example, Lagos Business School executive development programmes are rated very expensive, but perceived as good value for money. Nigeria Industrial Training Fund emphasizes affordability for its training and development programmes.

\subsection{Approaches for Generating and Evaluating Product Positioning Strategy}

Most of the approaches for the generation of new product ideas can be employed to develop positioning strategy. The normative analytical methods are also a viable approach in generating positioning strategy. This methods, suggest specific positioning strategies for specific conditions (Hanser and Shugan, 1983). Another significant approach is the Analytic Hierarchy Process (AHP) - group decision aid, which was developed by Thomas Saaty in 1980's - has been used as an approach to generate and evaluate marketing strategies (Dunn and Wind, 1986) and a variety of other marketing and business decisions (Wind and Saaty, 1980).

The Analytic Hierarchy Process illustrates formulations of hierarchies for the selection of positioning strategies and it focuses on the selection of target segments and then evaluates positioning strategy on their ability to meet the needs of the various segments. The Analytic Hierarchy Process (AHP) is an operational research model that is designed to solve complex problems involving multiple option or criteria (Dixon-Ogbechi et al., 2011).

Evaluating positioning strategy is often the most difficult part of the process. And to stimulate the generation of positioning options, it is desirable for the management to consider the taxonomy of alternative ways of positioning a product or service. The taxonomy approach for positioning a product is based on the premise that effective positioning has to be centered on meeting the bundle of current and expected benefits sought by the target segment and as a basis on which a product is likely to be differentiated from its competition (Crawford, 1985; Friedmann and Lessig, 1987).

The selection of a positioning strategy requires the explicit evaluation of the general positioning options on set criteria which range from product features, user, usage/application, price-value, competition etc. The selected criteria are then incorporated in a decision hierarchy to accomplish the firm's objectives. 


\section{Methodology and Method}

\subsection{Descriptive Research Method}

The present study is not an empirical study, rather it is theoretical one (secondary or desk research) which involves the summary, collation and /or synthesis of existing research rather than primary research.

This study has been conducted on the basis of reviewing marketing literature, which was collected and recorded prior to and for the purposes other than the current needs of the researcher (Harris, 2001). As depicted by name desk research. It is a research technique which is mainly acquired by sitting at a desk and it is often considered a low cost technique as compared to field research (Zikmund, 2003).

\section{Discussions}

Effective positioning helps firms attract new customers in the short run, and helps build customer-brand relationships in the long run. In addition, effective positioning by the firms in the same strategic group decreases direct competition and offers potential customer's choices in the market (Porter, 1980; Levitt, 1991). Furthermore, the long term objective of positioning is to build a brand equity, which will in turn achieve positive long term purchase behavior (Keller, 2008). Within the long term purchase behavior, a brand will achieve a superior market share, and good return on business and marketing investment. Details evidence of the impact of positioning strategy on firm core financial performance measures includes sales, profits, return on investment, market share, company image, and consumer perceptions (Blankson et al., 2008).

Positioning strategy can be conceived and implemented from different approaches and in a variety of ways that derive from the attributes, competition, specific applications/use, the types of consumers involved, or the characteristics of the product class and category. Each of this approach represents a strategy for developing a positioning strategy, with the ultimate goal of either developing or reinforcing a particular image for the brand in the mind of the consumer. The choice of positioning strategy is influenced by such factors as the competitive marketplace, specific corporate goals, and organizational strengths.

Positioning begins with a product, even though the concept is about positioning a product in the mind of the customer. The concept is relevant because consumers are bombarded with stream of advertising and marketing campaign and the consumer's mind reacts to high volume of advertising and marketing campaign by accepting only what is consistent with prior knowledge or experience.

Positioning is a way of getting into the mind of the consumer and the easiest way to do this is to be the first. Even if a competitor offers something better, the first movers will have a competitive advantage to counter the competitive shock. However, since all products are not going to be the first, it must strive to find an unoccupied position in which it can be first. At a time when larger cars were in vogue, Volkswagen introduced the Beetle with the marketing slogan "Think small." Beetle was not the first small car, but Volkswagen was the first to adopt the strategy to position Beetle in the mind of the consumer.

On a final note, a firm must not strive to build a brand by trying to appeal to everyone. A product that is position along this line will end up losing clear position and being nothing to everyone (Kotler, 1991).

\section{Conclusion}

Positioning strategy emerges as a result of the modern mentality and it is a form of expression of how certain product or brand is perceived by customers. It is not how products are presented or what is presented. However, for the success of brands, positioning and brand identity must be put forward clearly. Because the brand position and identity are connected in an intricate way in order to emphasize the differences.

Positioning strategy refers to the choice of target market segment which describes the customers a business will seek to serve and the choice of differential advantage which defines the basis of competition in the segment (Doyle, 1983). This definition shows that a positioning strategy only applies at the level of a particular product and/or service operating within a particular market segment, and that it should not be confused with the broader concept of "corporate strategy", or with the more specific concepts of strategy as it relates to marketing mix elements, such as a "promotion", "distribution" "or "pricing" strategy. Once a positioning plan has been finalized it is translated into action by assembling an appropriate marketing mix. However, no positioning strategy will last forever; this is because of changes in consumer's tastes and preferences, competitors, and technology.

The concept of positioning is applicable to products in the broadest sense. Institutions, Local Governments, States or even Countries can benefit from a well developed positioning strategy that focuses on a niche that is unoccupied in the mind of the consumer or decision maker. 
The concept of positioning, with its emergence has been of great interest in marketing communication and academia. It is increasingly recognized as one of the foundations of all marketing strategies, product and business strategy. At the product level, it is the desired positioning strategy for a target segment that provides the necessary inputs on product concept and design. At the marketing strategy level, positioning by segment is the pillar upon which the rest of the marketing mix program is built. Lastly, at the business unit level, the selected positioning strategy provides both the basis for the entire strategy and guidelines for the allocation of needed resources across the functional and strategic business units.

A positioning strategy reveals possible competitive advantages to create positioning, to select the right competitive strategy and to choose a comprehensive positioning strategy. According to (Kotler, 2000), the development of effective benefit - centered positioning involves three things. First, you have to understand what benefits are sought by the consumers and what the relative importance of those benefits is. Second, you have to understand how consumers perceive a firm and its product in relation to competitors on the basis of the benefits sought by consumers. Third, a firm has to know what products and services are bought and consumed by consumers.

\section{References}

Aaker, D.A., \& Shansby, J. (1982). Positioning Your Product. Business Horizions, 56-62. http://dx.doi.org/10.1016/0007-6813(82)90130-6

Advertising Age “Agency Report, 2008”, May 5, 2008.

Alden, D, Steenkamp, J.B., \& Bantra, R. (1999). Brand Positioning through Advertising in Asia, North America, and Europe: The Role of Global Consumer Culture. Journal of Marketing, 1999(63), 75-87. http://dx.doi.org/10.2307/1252002

Andreasen, A.R., \& Kotler, P. (2003). Strategic Marketing for Non-profit Organizations ( $^{\text {th }}$ eds.). Upper Saddle River, New Jersey: Pearson /Prentice-Hall.

Berkman, H.W., \& Gilson C. (1987). Consumer Behavior: Concepts and Strategies (3 ${ }^{\text {rd }}$ ed.). Boston: Kent Publishing Company.

Blankson C., Kalafatis S., Cheng J., \& Hadjicharalambous, C. (2008). Impact of Positioning Strategies on Corporate Performance. Journal Of Advertising Research, 48(1), 106-122. http://dx.doi.org/10.2501/50021849908080124

Caroll, J.D., \& Green, P. (1997). Psychometric Methods in Marketing Research: Part II, Multidimensional Scaling. Journal of Marketing Research, (34), 193-204. http://dx.doi.org/10.2307/3151858

Chew, C.P. (2005). Strategic Marketing Planning and Positioning in Voluntary Non-profit Organizations: Empirical Findings and Implications for British Charitable Organizations. Policy Studies and Services Management Group, Aston Business School, Aston University, Birmingham.

Crawford C.M. (1985). A new Positioning Typology. Journal of Product Innovation Management, 2, 243-253. http://dx.doi.org/10.1111/1540-5885.240243

Dinnie, K. (2008). Nation Branding, Concepts, Issues, Practice. Oxford: Butterworth-Heinemann.

Dixon-Ogbechi, B.N., Joseph, F.A., \& Elizebeth, H. (2011). Determination of the Strategic Relationship Marketing Mix of Companies in the Nigerian Service Industry using the Analytic Hierarchy Process Model. Proceedings of the International Symposium on the Analytic Hierarchy Process 2011.

Doyle, P. (1983). Marketing Management, Unpublished paper. Bradford University Management Centre.

Dunn, E., \& Wind, Y. (1986). Analytic Hierarchy Process for the Generation and Evaluation of Marketing Mix Strategies. In Gary Frazier and Jagadish Sheth (Eds), Contemporary Views on Marketing Practice. Lexington, MA: Lexington.

Far Eastern Economic Review. (2000). "Bull's -eye". 12 October, 2000.

Friedmann, R., \& Lessig, V.P. (1987). Psychological Meaning of Products and Product Positioning. Journal of Product Innovation Management, 4.

Green, P., Wind, A., Kreiger, P., \& Saatsoglou (2000). Applying Quantitative Data. Marketing Research, (12), $17-25$.

Hanser, J.R., \& Shugan S.M. (1983). Defensive Marketing Strategy. Marketing Science, 2. 
Harris, H. (2001). Content Analysis of Secondary Data: A Study of Courage in Managerial Decision Making. Journal of Business Ethics, 34(3/4), 191-208. http://dx.doi.org/10.1023/A:1012534014727

Hiroyuki, I., \& Thomas, R.W. (1987). Mobilizing Invisible Assets. Harvard University Press, Cambridge, M.A.

Hooley, G., Greenley, G., Fahy, J., \& Cadogan, J. (2001). Market-focused Resources, Competitive Positioning and Firm Performance. Journal of Marketing Management, 17, 503-520. http://dx.doi.org/10.1362/026725701323366908

Hooley, G., Saunders, J.A., \& Piercy, N.F. (1998). Marketing Strategy and Competitive Positioning (2nd ed.). Harlow: Prentice-Hall.

Kapferer, J. N. (1997). Strategic Brand Management (2 ${ }^{\text {nd }}$ ed.). Dover, N.H: Kogan Page.

Keller, K. (2008). Strategic Brand Management: Building, Measuring, and Managing Brand Equity. University of California: Prentice Hall, 1-67.

Keller, K.L. (1993). Conceptualising, Measuring and Managing Consumer Based Brand Equity. Journal of marketing, 57(1), 1-12.

Kotler, P. (1991). Marketing Decision Making. Harper and Row Publishers

Kotler, P. (2000). Marketing Management: Analysis, Planning, Implementation and Control (10 ${ }^{\text {th }}$ ed.). New Jersey: Prentice -Hall.

Kotler, P., \& Andreasen, A.R. (1996). Strategic Marketing for Non-profit Organizations (5 ${ }^{\text {th }}$ ed.). New Jersey: Pearson Education/Prentice-Hall, Upper Saddle River.

Kotler, P., \& Armstrong, G. (2006). Principles of Marketing (11 ${ }^{\text {th }}$ ed.). USA: Prentice Hall.

Kotler, P., \& Keller, K.L. (2006). Marketing Management (12 ed.). Upper Saddle River: Prentice-Hall.

Levitt, T. (1991). Thinking about Management. Boston, M.A: Harvard Business School Press.

Lovelock, C.H. (1991). Services Marketing (2nd ed.). Prentice- Hall.

Lovelock, L., \& Weinberg, C. (1989). Public and Nonprofit Marketing (2nd ed.). Redwood City, CA: The Scientific Press.

Micheal, T., \& Fred W. (1993). The Discipline of Market Leaders. Reading Mass: Addison-Wesley, Publishing Company.

Myers, J. (1996). Segmentation and Positioning for Strategic Marketing Decisions. Chicago, H: American Marketing Association.

Oliver, R.L. (1997). Measurement and Evaluation of Satisfaction Process in Retail Setting. Journal of Retailing, 57, $25-48$.

Pham, M.T., \& Muthukrishnan A.V. (2002). Search, Alignment, and Judgment Revision: Implications for Posting. Journal of Marketing Research, 39(February). 18-30. http://dx.doi.org/10.1509/jmkr.39.1.18.189.29

Porter, M. (1980). Competitive Strategy. New York: The Free Press.

Ries, A., \& Trout, J. (2001). Positioning: The battle for Your Mind (20 ${ }^{\text {th }}$ anniversary ed.). Boston: McGraw-Hill.

Ries, J., \& Trout A. (1981). Positioning: The Battle for Your Mind. Warner Book - New York: Mc Graw Hill.

Thomas, L.S. (1980). Decisions Making with the Analytic Hierarchy Process. International Journal of Services Sciences, 1(1), 2008.

Vukasovic, T. (2009). Searching for competitive advantage with the aid of the brand potential index. Journal of Product and Brand Management, 18(3), 165-176.

Whan, C.P., Bernard, J., \& Deborah, J.M. (1986). Strategic Brand Concept-Image Management. Journal of Marketing, 50, 135-145.

Wind, Y., \& Saaty, T. (1980). Marketing Applications of the Analytic Hierarchy Process. Marketing Science, 26, 641-658.

Zikmund, W.G. (2003). Business Research Methods. USA: Thouson Learning. 